\title{
TINGKAT KELANGSUNGAN HIDUP DAN PERTUMBUHAN BENIH TERIPANG (Holothuria atra) HASIL REPRODUKSI ASEKSUAL DENGAN BERAT YANG BERBEDA
}

\section{SURVIVAL AND GROWT RATE OF SEED SEA CUCUMBER (Holothuria atra) RESULTED BY ASEXUAL REPRODUCTION IN DIFFERENT WEIGHT}

\author{
Yani Robiansyah $^{1 *}$, Nurliah $^{1)}$, Siti Hilyana ${ }^{1)}$ \\ ${ }^{1)}$ Program Studi Budidaya Perairan, Fakultas Pertanian, Universitas Mataram \\ Jl. Pendidikan No, 37 Mataram, NTB
}

\begin{abstract}
Abstrak
Fission merupakan sistem reproduksi aseksual teripang (Holothuria atra) dengan cara pembelahan bagian tubuh yang dapat membentuk individu baru sehingga dapat digunakan sebagai alternatif perbanyakan individu teripang.Tujuan penelitian ini untuk mengetahui pengaruh perbedaan berat tubuh teripang terhadap tingkat kelangsungan hidup dan pertumbuhan teripang hasil fission.Penelitian ini menggunakan rancangan acak lengkap (RAL) dengan perlakuan Kontrol (150-350 gram/ tanpa fission), P1 (150 gram), P2 (250 gram) dan P3 (350 gram). Data uji analisis menggunakan ANOVA dengan taraf $5 \%$ untuk mengetahui perlakuan terbaik. Berdasarkan hasil penelitian menunjukan perbedaan berat tubuh teripang memberikan pengaruh terhadap tingkat kelangsungan hidup namun tidak meberikan pertumbuhan terhadap benih teripang hasl fission. Kelangsungan Hidup tertinggi didapat pada perlakuan Kontrol (100\%) dan P2 (72,22\%). Sedangkan untuk pengamatan morfologis dan Fisiologis teripang memberikan hasil yang berbeda setiap minggunya.
\end{abstract}

Kata kunci : fission, teripang (holothuria atra), berat berbeda

\begin{abstract}
Fission is an asexual reproductive system of the sea cucumbers (Holothuria atra) by dividing body parts that can form new individuals. This system can be used as an alternative to enchance the sea cucumber individuals. The purpose of this study was to determine the effect of differences in sea cucumber body weight on sea cucumber survival and growth rates based on the results of fission. This study used a complete randomized design and control treatment (150-350 grams / without fission), P1 (150 grams), P2 (250 grams), and P3 (350 grams). Each treatment was repeated six times to obtain 24 experimental units. The analysis test data used ANOVA with a level of 5\% to find out the best treatment. Based on the results of the study, it showed the differences in the body weight of the sea cucumbers which influence the survival rate. However, it did not give growth to sea cucumber seeds as a result of fission. There was the highest of survival that obtained from the control treatment $(100 \%)$ and P2 (72.22\%). Then, for the morphological and physiological observations of the sea cucumbers gave different results every week.
\end{abstract}

Keywords : fission, sea cucumbers (Holothuria atra), the different weights

\section{Pendahuluan}

Teripang merupakan salah satu filum echinodermata yang banyak dimanfaatkan sebagai bahan makanan karena mengandung nutrisi yang tinggi, selain itu teripang juga bermanfaat sebagai obat-obatan. Karnila (2011) menyatakan teripang mengandung komponen bioaktif yang dapat menyembuhkan berbagai macam penyakit seperti diabetes, obesitas dan hipertensi, karena itu teripang memiliki nilai ekonomisyang tinggi,harga 
teripang didalam negeri mencapai 50.000$1.200 .000 / \mathrm{kg}$, sedangkan di pasar ekspor harganya mencapai US\$ 15,06 per $\mathrm{Kg}$ (Rumlus dkk., 2015).

Secara ekologis teripang berperan penting dalam rantai makanan (food chain) di perairan, selain itu, biologi perilaku teripang dalam mendapatkan makanan membantu proses dekomposisi zat organik yang terdapat dalam sedimen. Menurut Elfidasari (2012), teripang berperan sebagai penyumbang makanan berupa telur dan juwana teripang bagi krustasea, molluska dan ikan. Tingkah laku teripang yang "mengaduk" dasar perairan sebagai cara mendapatkan pakannya, membantu menyuburkan substrat disekitarnya serta mencegah penumpukan bahan organik, proses tersebut dapat menekan pertumbuhan bakteri tertentu.

Provinsi Nusa Tenggara Barat merupakan salah satu penghasil teripang terbesar di Indonesia, namun dalam sepuluh tahun terakhir populasi teripang dialam cenderung menipis dikarenakan pemanfaatan teripang sebagai salah satu sumber nafkah nelayan sejak dua dekade terakhir.Nelayan teripang tidak bisa lagi mengumpulkan sumberdaya ini di lokasi yang dekat tetapi sudah mulai harus melakukan perjalanan jauh dalam mengumpulkan teripang yang berukuran kecil. Ancaman pemanfaatan teripang secara komersial saat ini sudah menjadi perhatian internasional yang melibatkan CITES. (Dwiono 2008).

Untuk menjaga kelestarian dan kelangsungan hidup teripang di alam, perlu dilakukan pembenihan baik reproduksi seksual maupun aseksual. Widianingsih dkk., (2013) menyatakan pada usaha reproduksi seksual masih terdapat berbagai masalah salah satu keberhasilan fertilisasi tergantung dari jumlah induk di alam, masa kritis larva dan juvenil yang tinggiserta untuk mendapatkan induk yang matang gonad tergantung musim.

Produksi benih melalui reproduksi seksual belum dapat diandalkan karena jumlah juvenil yang dihasilkan masih sedikit. Sementara itu, beberapa jenis teripang memiliki kemampuan untuk berkembang biak secara aseksual dengan membelah (fission). Purwati (2002) menyatakan terdapat 10 jenis teripang yang termasuk fisiparus holothurians (dapat melakukan reproduksi aseksual melalui fission), hanya 3 jenis teripang yang memliki nilai ekonomis salah satunya $H$. atra, $H$. leucospilota, dan $S$. chloronotus.

Menurut Emson dan Wilkie (1980) fission adalah proses pembelahan satu individu menjadi dua individu. Kedua bagian ini akan tumbuh menjadi individu utuh setelah masingmasing menumbuhkan kembali bagian yang hilang. Perbanyakan dengan pembelahan ini tidak memerlukan induk yang banyak seperti halnya produksi benih melalui reproduksi seksual dengan teknik yang relative mudah, murah dan dapat dimulai dari jumlah yang sedikit. (Purwati 2001 ; Purwati ; 2002 ; Purwati dan Dwiono 2005).

Penelitian mengenai fission teripang sudah banyak dilakukan namun ditemukan kendala yaitu rendahnya tingkat kelangsungan hidup teripang hasil fission. Hal ini dikarenakan teripang mengalami luka akibat pembelahan sehingga tidak dapat mempertahankan kelangsungan hidupnya. Namun demikian penggunaan antibiotik alamipun belum mampu meningkatkan tingkat kelangsungan hidup (27\%) teripang hasil fission (Satria 2018). Hal ini diduga karena belum didapatkan ukuran yang ideal dalam reproduksi aseksual teripang. Penelitian lain yang dilakukan Purwati (2002) bahwa ukuran spesimen yang digunakan dalam propagasi aseksual dapat menjadi penentu keberhasilan. Hal ini sudah dibuktikan oleh Karimdkk (2013) yang menggunakan jenis teripang Holothuria edulis dan Holothuria leocospolita yang menyimpulkan bahwa perbedaan jenis dan berat teripang dapat mempengaruhi tingkat kelangsungan hidup, daya regenerasi serta proses penutupuan luka teripang hasil fission. Sedangkan penelitian tentang berat ideal Holothuria atra dalam reproduksi aseksual belum pernah dilakukan.

Dengan demikian untuk meningkatkan keberhasilan produksi aseksual teripang Holothuria atra maka perlu dilakukan penilitian mengenai teknik stimulasi fission teripang dengan berat yang berbeda sebagai salah satu teknik perbanyakan individu Holothuria atra.

\section{Metode Penelitian}

Penelitian dilakukan selama 45 hari (JuliAgustus 2018) di Balai Pengembangan Budidaya Perikanan Pantai Sekotong, Lombok Barat. Menggunakan Rancangan Acak Lengkap (RAL). Empat perlakuan dan enam 
ulangan : Kontrol (tanpa fission):150-350 gram \pm 10 gram, Perlakuan pertama (P1) :150 gram \pm 10 gram, Perlakuan kedua (P2) :250 gram \pm 10 gram, Perlakuan ketiga (P3) :350 gram \pm 10 gram .

\section{Pelaksanaan Penelitian}

Specimen uji adalah 72 individu Holothuria atra dengan bobot 150-350 gram yang diperoleh dari pengepul di Kecamatan Sekotong, Lombok Barat. Sebelum dilakukan pemotongan teripang terlebih dahulu diukur panjang dan berat awal. Purwati dan Dwiono (2005) dalam Widianingsih dkk. (2014) menyatakan teknik Stimulasi fission dilakukan dengan mengikat teripang uji dengan karet pentil pada posisi $1 / 3$ bagian tubuh teripang. Teripang yang sudah diikat dimasukan kedalam keranjang yang sudah disiapkan pada bak fiber yang sudah terisi air. Proses pembelahan ini berlangsung selama 12 sampai 24 jam.

Pada tahapan selanjutnya individu hasil fission teripang diletakan didalam keranjang dan dipelihara selama 45 hari, pada saat pemeliharaan individu hasil fission diberi pakan dan dilakukan pergantian air dalam wadah pemeliharaan.

Pakan yang diberikan selama masa pemeliharaan teripang hasil fission yaitu lamun jenis Enhalus accoroides yang diambil di perairan Sekotong, Lombok Barat. Sebelum pakan diberikan terlebih dahulu dicuci untuk menghilangkan kotoran atau organisme yang menempel pada lamun. Setelah itu lamun dipotong kecil lalu dihaluskan menggunakan blender bertujuan agar teripang mudah menyerap pakan yang yang diberikan. Pemberian pakan dilakukan sebanyak satu kali yaitu pada sore hari pukul 17:00 mengingat sifat teripang yang aktif pada malam hari (Nocturnal) dengan dosis 5\% Bobot tubuh. Sisa pakan yang di blender dapat disimpan kembali didalam kulkas.

Pergantian air media pemeliharaan pada penelitian ini dilakukan setiap hari pada pukul 08:00 sebanyak 50\%. Hal ini bertujuan untuk menyediakan lingkungan yang optimal selain itu penggunaan aerasi sebanyak 9 titik/bak sebagai suplai oksigen dalam wadah pemeliharaan sehingga dapat menunjang kehidupan benih teripang hasil fission. Sebelum penambahan air baru media air di dalam bak fiber dikurangi dengan cara membuka pintu outlet yang terdapat pada bak fiber. Setelah itu penambahan air baru dilakukan menggunakan selang.

\section{Analisa Data}

Parameter yang diuji secara statistik adalah pertumbuhan berat spesifik $=S G R=$ $\frac{\ln W \mathrm{t}-\ln \mathrm{Wo}}{\mathrm{t}} \times 100$; pertumbuhan panjang spesifik $=S G R=\frac{\ln \mathrm{Lt}-\ln \mathrm{Lo}}{\mathrm{t}} \times 100$ pertumbuhan berat mutlak $=G=W_{t}-W_{0}$; pertumbuhan panjang mutlak $=L=L t-L o$; tingkat kelangsungan hidup $=\mathrm{SR}=\frac{N t}{N o} \times 100 \%$.

Pengamatan morfologis dilakukan secara visual yang bertujuan untuk melihat kondisi teripang hasil fission yang diamati setiap minggu, Dengan cara melihat pergerakan teripang, stress, teripang yang aktif mengeluarkan lendir dan pemulihan luka hasil fission.

Pada pengukuran parameter kualitas air, pengamatan dilakukan untuk menjadi parameter pendukung yang diamati. Adapun parameter kualitas air yang akan diuji yaitu suhu, salinitas, $\mathrm{pH}$, DOdan salinitas yang akandiukur satu kali seminggu. Data yang telah dikumpulkan selama proses penelitian dianalisis menggunakan ANOVA (analysis of variance) pada taraf 5\% dan dilakukan uji lanjut Tukey (HSD) pada taraf nyata 5\%jika hasil menunjukkan perbedaan yang signifikan.

\section{Hasil}

Hasil pengamatan morfologis dan fisiologis yang dilakukan selama penelitian didapatkan hasil yang berbeda setiap minggunya. Pengeluaran lendir pada teripang merupakan respon teripang yang mengalami pembelahan terlihat dari minggu pertama sedangkan teripang tanpa fission pada minggu pertama mengalami stress (mengeluarkan isi perut), kesehatan teripang mulai membaik pada minggu kedua dimana teripang aktif menempel di dinding keranjang, pemulihan luka pada teripang hasil fission terjadi pada minggu keempat sampai minggu keenam, keadaan teripang kembali menurun pada minggu kelima dan akhir minggu keenam ditandai dengan teripang mengeluarkan cincin kapur pada tubuhnya.Secara tabel Pengamatan morfologis dan fisiologis teripang disajikan pada Tabel 1. 
Tabel 1. Pengamatan morfologis dan fisiologis

\begin{tabular}{|c|c|c|c|c|c|c|c|c|}
\hline \multirow{2}{*}{\multicolumn{2}{|c|}{ Parameter }} & \multicolumn{7}{|c|}{ Minggu } \\
\hline & & 1 & 2 & 3 & 4 & 5 & 6 & 7 \\
\hline Lendir & $\begin{array}{c}\text { Ada } \\
\text { tidak ada }\end{array}$ & $\begin{array}{l}\text { P1, } \\
\text { P2, } \\
\text { P3 }\end{array}$ & & & & & & \\
\hline $\begin{array}{l}\text { Stress } \\
\text { (isi perut) }\end{array}$ & $\begin{array}{c}\text { Keluar } \\
\text { tidak keluar }\end{array}$ & $\begin{array}{l}\text { K1, } \\
\text { K2, } \\
\text { K3 }\end{array}$ & & & & & & \\
\hline $\begin{array}{l}\text { Penempel- } \\
\text { an }\end{array}$ & $\begin{array}{l}\text { Menempel } \\
\text { tidak } \\
\text { menempel }\end{array}$ & $\begin{array}{l}\mathrm{P} 1, \\
\mathrm{P} 2, \\
\mathrm{P} 3, \\
\mathrm{~K}\end{array}$ & $\begin{array}{l}\text { P1, } \\
\text { P2, } \\
\text { P3 } \\
\text { K }\end{array}$ & $\begin{array}{l}\text { P1, } \\
\text { P2, } \\
\text { P3, } \\
\text { K }\end{array}$ & $\begin{array}{l}\text { P1, } \\
\text { P2, } \\
\text { P3 } \\
\text { K }\end{array}$ & $\begin{array}{l}\text { P1, } \\
\text { P2, } \\
\text { P3, } \\
\text { K }\end{array}$ & $\begin{array}{l}\text { P1, } \\
\text { P2, } \\
\text { P3, } \\
\text { K }\end{array}$ & $\begin{array}{l}\text { P1, } \\
\text { P2, } \\
\text { P3, } \\
\text { K }\end{array}$ \\
\hline $\begin{array}{l}\text { Cincin } \\
\text { kapur }\end{array}$ & $\begin{array}{c}\text { ada } \\
\text { tidak ada }\end{array}$ & & & & & $\begin{array}{l}\text { P2, } \\
\text { P3 }\end{array}$ & P1 & \\
\hline $\begin{array}{l}\text { Pemulih- } \\
\text { an luka }\end{array}$ & $\begin{array}{c}\text { Tertutup } \\
\text { tidak tertutup }\end{array}$ & & & & $\mathrm{P} 2$ & & $\begin{array}{l}\text { P1, } \\
\text { P3 }\end{array}$ & \\
\hline
\end{tabular}

cenderung mengalami penyusutan berat tubuh. Hasil uji lanjut Tukey menunjukkan penyusustan berat tertinggi didapat pada perlakuan P1($139.49 \pm 1.65 \%)$ diikuti $\mathrm{P} 3$ $(-324.83 \pm 10.03 \%)$ dan P2 $(-170.11 . \pm 32.90 \%)$.

Sedangkan penyusutan bobot pada perlakuan $\mathrm{K} 1$ $(-15.50 . \pm 3.14 \%)$ didapatkan hasil yang tidak berbeda nyata.Secara grafik pertumbuhan berat mutlak disajikan pada Gambar 3.
Hasil pengukuran berat teripang yang dilakukan pada akhir penelitian menunjukan teripang mengalami penuyusutan berat tubuh. Berdasarkan hasil uji anova perbedaan berat tubuh teripang memberikan hasil yang signifikan $(\mathrm{p}<0,05)$ terhadap laju pertumbuhan berat spesifik teripang. Hasil uji lanjut tukey menunjukkan penyusutan berat spesifik tertinggi didapatkan pada perlakuan P3 $(-6.47 \pm 1.05 \%)$ diikuti P1 $(-5.95 \pm 0.29 \%)$ dan P2 $(-3.33 \pm 1.05 \%)$. Sedangkan pada perlakuan K1 (-0.16\% \pm 0.28$)$ memberikan hasil yang tidak berbeda nyata. Secara grafik pertumbuhan spesifik disajikan pada Gambar 1.

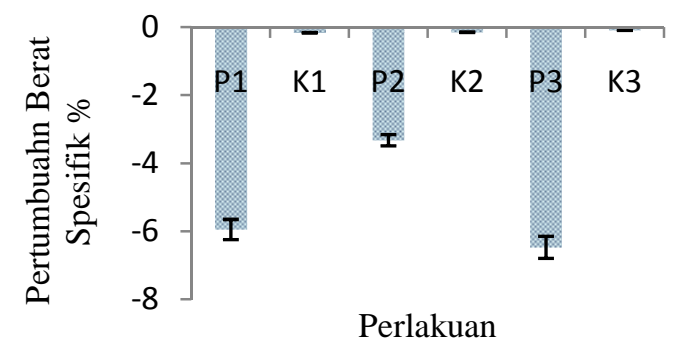

Gambar 1. Pertumbuhan berat spesifik

Berdasarkan hasil pengukuran bobot mutlak yang dilakukan pada akhir pemeliharaan didapat hasil yang signifikan $(\mathrm{P}<0,05)$ terhadap laju pertumbuhan mutlak teripang. Namun pada setiap perlakuan

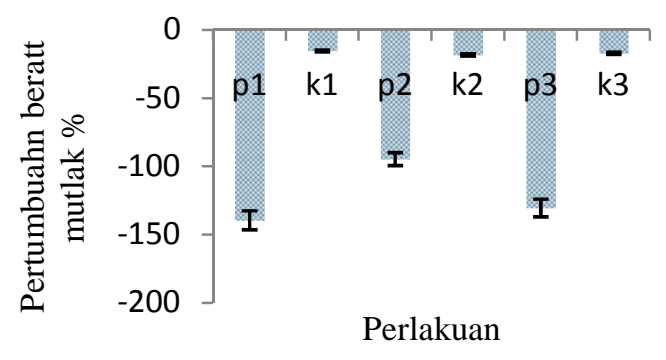

Gambar. 2 Pertumbuhan berat mutlak

Berdasarkan hasil pengukuran panjang spesifik teripang yang dilakukan pada akhir penelitian, teripang mengalami penyusutan panjang. Hasil uji anova perbedaan berat tubuh teripang memberikan hasil yang signifikan $(\mathrm{p}<0,05)$ terhadap pertumbuhan panjang spesifik teripang. Hasil uji lanjut tukey menunjukkan penyusutan panjang tertinggi yaitu pada perlakuan P3 $(-4,54 \pm 1.49 \%)$ dan P1 $(-3.29 \pm 1.47 \%)$. Sedangkan nilai rata-rata pada perlakuan P2 (-1,12 $\pm 0.73 \%)$ dan kontrol ($0.20 \pm 0.80 \%$ ) memberikan hasil yang tidak berbeda nyata. Secara grafik pertumbuhan panjang spesifik disajikan pada Gambar 3 .

Hasil pengukuran pertumbuhan panjang mutlak yang dilakukan pada akhir penelitian menunjukan teripang hasil fissionmengalami penyusutan panjang. Hasil uji anova perbedaan berat tubuh teripang memberikan hasil yang signifikan $(\mathrm{p}<0,05)$ terhadap pertumbuhan panjang mutlak teripang. Hasil uji lanjut tukey penyusutan panjang mutlak 
tertinggi didapat pada perlakuan P3 sebesar

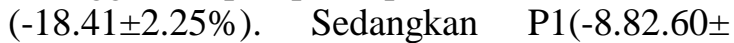
$2.25 \%)$ dan P2 (-6.29 $\pm 3.60 \%)$ menunjukkan hasil yang tidak berbeda nyata. Selanjutnyanilai rata-rata perlakuan Kontrol ($1,48 \pm 0,46 \%)$ tidak memiliki perbedaan yang signifikan.Secara grafik pertumbuhan panjang mutlak dapat dilihat pada Gambar 4.

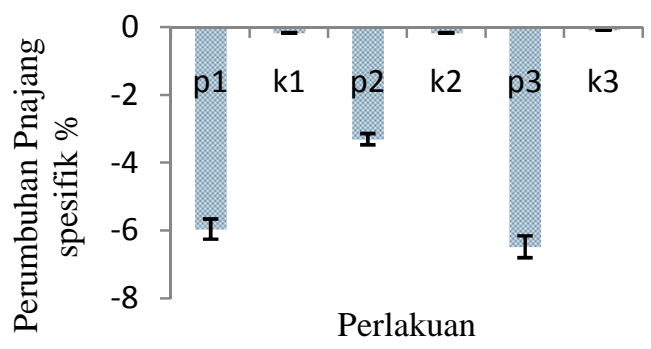

Gambar 3. Grafik pertumbuhan panjang spesifik

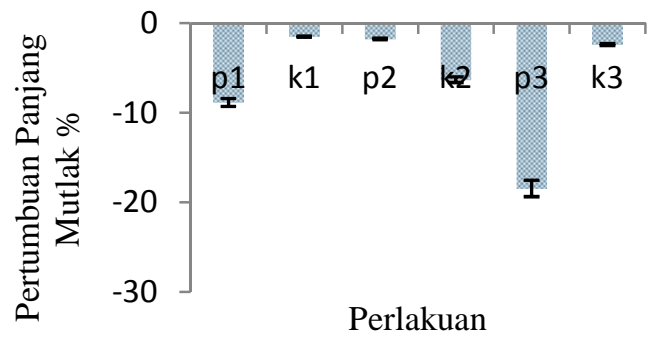

Gambar 4. Grafik pertumbuhan panjang mutlak

Berdasarkan jumlah individu yang hidup sampai akhir penelitian teripang hasil fissionmenunjukan hasil yang signifikan $(\mathrm{p}<0.05)$ yang Artinya perbedaan berat tubuh teripang mempengaruhi tingkat kelangsungan hidup teripang hasil fission. Hasil uji lanjut tukey didapatkan tingkat kelangsungan hidup tertinggi pada perlakuan Kontrol (100\%) diikuti P2 sebesar 72,22\%. Sedangkan perlakuan P3 sebesar 27,78 \% dan P1 sebesar $22,22 \%$ memberikan hasil yang tidak berbeda nyata.Secara grafik tingkat kelangsungan hidup disajikan pada Gambar 5.

Berdasarkan hasil pengukuran kualitas air yang dilakukan seiap minggu didapatkan bahwa suhu yang didapatkan berkisar antara $28{ }^{\circ} \mathrm{C}-29{ }^{\circ} \mathrm{C}$, salinitas berkisar antara $31-33$ ppt, pH berkisar antara $7.7-8.1$ sedangkan kandungan oksigen terlarut berkisar antara 5-6 $\mathrm{mg} / \mathrm{l}$.

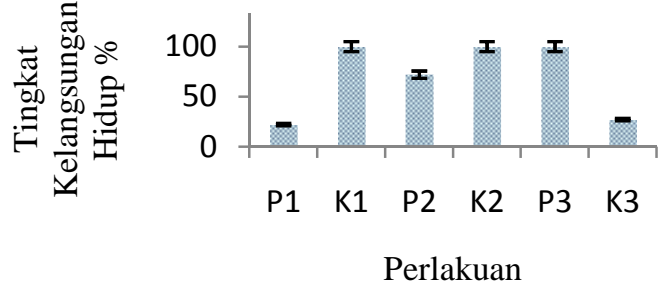

Gambar.5 Grafik tingkat kelangsungan hidup

Pembahasan

\section{Pengamatan Morfologis dan Fisiologis}

Pengamatan morfologis dan fisiologis teripang yang dilakukan secara visual bertujuan untuk melihat kondisi teripang hasil fission setiap minggu.parameter pengamatan yang dilihat yaitu teripang yang aktif mengeluarkan lendir, stress (pengeluaran isi perut) penempelan, pemulihan luka hasil fissiondan cincin kapur.

Pengamatan minggu pertama teripang pasca fission pada perlakuan P1 (150 gram), P2 (250 gram) dan P3 (350 gram) menunjukkan teripang kurang aktif bergerak dan berdiam diri didasar keranjang.Teripang pasca fission mengeluarkan lendir pada tubuhnya seperti tersaji pada Gambar 6. Hal ini diduga sebagai respon teripang yang mengalami pembelahan diakibatkan luka yang dihasilkan pasca fission. Keadaan fisiologis teripang yang mengeluarkan lendir merupakan upaya teripang untuk menghambat masuknya parasit dan pathogen penyebab penyakit pada luka hasil fission. Menurut Rottman dkk (1992) Lendir adalah penghalang fisik pertama yang menghambat masuknya mikroba dari lingkungan ke dalam tubuh ia bertindak sebagai penghalang kimia yang mengandung enzim dan antibodi yang dapat membunuh organisme penyebab penyakit yang menyerang.

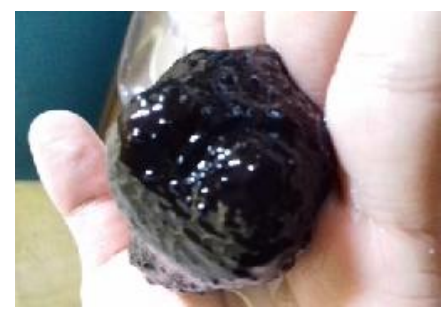

Gambar. 6 Pengeluaran lendir

Pada minggu kedua teripang hasil fission pada perlakuan P1, P2 dan P3 mulai aktif 
menempel di dinding keranjang sampai minggu ketujuh seperti tersaji pada Gambar 7. Hal ini menunjukkan keaadan teripang yang sudah mulai membaik serta teripang hasil fission sudah mulai beradaptasi dengan lingkungan baru hal ini sesuai dengan pernyataan. Ruppert dan Barnes (1996) dalam Smilek and Hembree (2012) mengemukakan bahwa teripang di habitatnya ada yang bersifat menempel pada tumbuhan laut, membenamkan diri di dalam substrat, menopang di atas substrat dan bersembunyi di celah-celah batu.

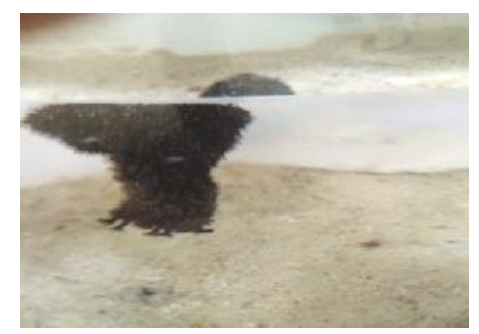

\section{Gambar 7. Penempelan teripang}

Pada minggu keempat didapatkan hasil kondisi kesehatan teripang pasca fission perlakuan P2 sudah melakukan recovery atau pemulihan luka pada tubuhnya sedangkan pada perlakuan P1 dan P3 proses penutupan luka terjadi pada minggu keenam yang ditandai dengan luka pada ujung tubuh teripang mulai menutup dan berwarna hitam, hal ini menunjukkan kondisi kesehatan teripang semakin membaik seperti tersaji pada Gambar 8. Muttaqin dkk (2012) menyatakan Proses penutupan lukaumumnya selesai pada hari ke-31 sampaidengan hari ke-64.

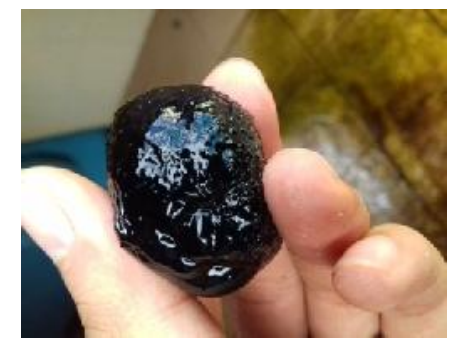

Gambar 8. Pemulihan luka

Pada minggu kelima dan keenam pada perlakuaan P1, P2 dan P3 kondisi kesehatan teripang kembali menurun dimana teripang kurang aktif bergerak dan tubuh teripang kurang segar, hal ini diduga teripang hasil fission mengalami stress berat ditandai dengan keluarnya bercak berwarna putih pada tubuh teripang yang didisebut dengan cincin kapurseperti tersaji pada Gambar 9. Rumiyati (2014) menyatakan tingkah laku mengeluarkan isi perut dan mengeluarkan cincin kapur terkadang tidak dilakukan teripang yang mengalami kematian.Hal tersebut diduga disebabkan teripang mengalami stres berat.

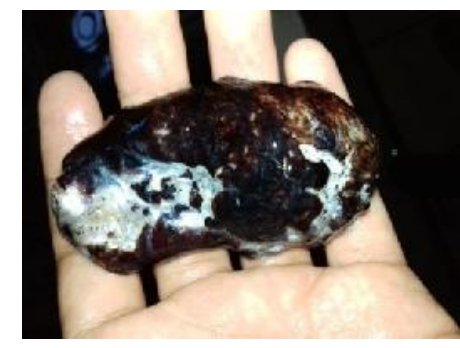

Gambar 9. Cincin kapur

Pada pengamatan morfologis dan fisiologi perlakuan Kontrol atau tanpa Fission pada minggu pertama kesehatan teripang menurun dimana teripang mengalami stress berat ditandai dengan keluarnya isi perut melalui anterior. Pengeluaran isi perut pada teripang merupakan perilaku abnormal dari teripang. Hal ini disebabkan teripang belum dapat berdaptasi dengan lingkungan baru sehingga membuat teripang cenderung diam didasar keranjang dapat dilihat pada Gambar 10. Rumiyati (2014) menyatakan Ketidakmampuan teripang dalam beradaptasi akan mempengaruhi fisiologi teripang yang ditunjukkan dengan beberapa tingkah laku seperti dikeluarkannya usus, gonad saat stress berat.

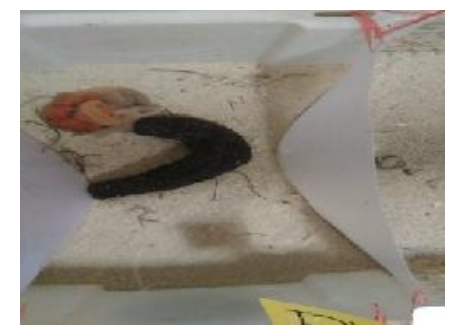

Gambar 10. Pengeluaran isi perut

Pada minggu kedua keadaan teripang perlakuan Kontrol (tanpa fission) mulai membaik ditandai dengan aktif menempel pada dinding keranjang serta mulai membuka mulut. 


\section{Pertumbuhan Berat Mutlak dan Spesifik}

Pertumbuhan adalah perubahan ukuran baik panjang, berat maupun volume dalam kurun waktu tertentu, atau dapat juga diartikan sebagai pertambahan jaringan akibat dari pembelahan sel secara mitosis, yang terjadi apabila ada kelebihan pasokan energi dan protein. Berdasarkan hasil uji anova didapatkan laju pertumbuhan hasil fission yang signifikan karena nilai $\mathrm{p}<0.05$ yang artinya memberikan pengaruh terhadap pertumbuhan benih teripang hasil fission, namun pada pengamatan pertumbuhan teripang hasil fission pada semua perlakuan, teripang tidak mengalami pertambahan berat tubuh sebaliknya teripang hasil fission mengalami penurunan berat tubuh. Hal ini diakibatkan tubuh teripang mengalami pembelahan yang membuat organ tubuh teripang hasil fission belum terbentuk serta teripang menggunakan energi untuk meregenerasi tubuhnya kembali akibat luka yang dihasilkan pada saat fission. Penurunan bobot tubuh pada teripang merupakan konsekuensi non makan yang dilakukan oleh fissioparus.(Emson dan Maldenov 1987; Conand dkk1997).

Purwati (2007) mengemukakan bahwa selama teripang melakukan regenerasi tentakel dan podia tidak aktif dalam mengambil pakan sehingga menyebabkan minimumnya metabolisme teripang.Selain itu, energi teripang dialokasikan untuk pemulihan dan regenerasi. Pernyataan ini diperkuat oleh Laxminaryana (2006) bahwa teripang hasil fission pada saat proses penutupan luka akan mengalami penurunan bobot tubuh. Hal ini dikarenakan individu hasil fission belum membentuk mulut dan anus baru sehingga proses makan tidak berlangsung. Individu hasil fissionakan membentuk tentakel, mulut dan pori-pori baru selama 2-3 bulan.

Dugaan lain yang menyebabkan rendahnya pertumbuhan benih teripang hasil fission dikarenakan faktor stress yang dapat menyebabkan teripang kurang aktif dalam mengambil pakan yang diberikan sehingga tidak dapat mencukupi kebutuhan energi yang dibutuhkan oleh tubuhnya. Barton dkk (1987) menyatakan bahwa stressor dapat mempengaruhi pertumbuhan melalui proses penyerapan atau pemanfaatan pakan. Werd and Comen (1998) menyatakan stress yang sering terjadi dalam jangka waktu yang lama, akan menyebabkan biota tidak dapat beradaptasi sehingga akan mempengaruhi pertumbuhan, apabila biota mengalami stress akan mempengaruhi proses metabolisme dan menyebabkan perubahan anggaran energi yang digunakan.

\section{Pertumbuhan Panjang Mutlak dan Spesifik}

Pada pengamatan perumbuhan panjang mutlak teripang berdasarkan hasil uji anova didapatkan hasil yang signifikan $(\mathrm{p}<0.05)$ artinya perbedaan beratt tubuh memberikan pengaruh yang signifikan terhadap panjang mutlak dan panjang spesifik teripang. Namun pada pengamatan terhadap panjang teripang hitam, teripang tidak mengalami pertambahan panjang tubuh. Hal ini diduga karena pada saat pengukuran panjang teripang sering memanjang dan memendekkan tubuhnya.Purwati \& Dwiono (2004) menyatakan bahwa tubuh teripang mudah sekali mengkerut dan menjulur.Menurut Purwati dkk (2009).Hal tersebut dikarenakanpanjang badan teripang sewaktuwaktu dapatberubah (memanjang atau memendek) sesuai kondisilingkungan. Selain itu, material yang terdapat dalam badanteripang sebagian besar terdiri atas air yang dapatmembentuk badan teripang setiap saat.

\section{Tingkat Kelangsungan Hidup}

Tingkat kelangsungan hidup adalah presentase organisme yang hidup diakhir penelitian dalam suatu waktu tertentu. Teripang yang masih hidup ditandai dengan masih aktif melakukan proses fisika, kimia dan biologi. Sedangkan teripang yang sudah mati ditandai dengan tubuh yang berwarna cokelat serta mengeluarkan bau busuk. Tingkat kelangsungan hidup tertinggi terdapat pada perlakuan kontrol (100\%) dan P2 (250 gram) sebesar $72.22 \%$ sedangkan perlakuan p3 (350 gram) (27.78\%) dan P1 (150 gram) (22.22 \%) memberikan hasil yang tidak berbeda nyata. Rendahnya tingkat kelangsungan hidup pada perlakuan P1 (150 gram) hal ini dikarenakan ukuran yang kecil pada saat fission membuat tingkat kestresan yang tinggi sehingga mempengaruhi tingkat kelangsungan hidup teripang. Hal ini sesuai dengan pernyataan Prastiwi (2011) mengemukakan bahwa kelangsungan hidup menurun pada teripang dikarenakan respon dari teripang yang telah dipotong mengalami stress dan tidak dapat mempertahankan kelangsungan hidupnya. Selain itu Anderson (1996) mengatakan bahwa 
stres berpengaruh pada jalur metabolik yang menekan sistem imunitas biota. Sedangkan rendahnya tingkat kelangsungan hidup pada perlakuan P3 (350 gram) diduga karena ukuran yang sudah tua/dewasa menyebabkan jaringannya tidak dapat menutupi luka akibat fission karena kehabisan energi dalam meregenerasi tubuhnya.Purwati (2005) menyatakan bahwa kemampuan beregenerasi teripang tidak terlepas dari keberadaan fungsi jaringan pengikat. Jaringan ini merupakan jaringan dasar selain sebagai pendukung mekanik, tempat pertukaran materi metabolit, tempat penyimpanan energi dan protektor, juga berfungsi sebagai pemulih jaringan.

$$
\text { Sedangkan tingginya tingkat }
$$

kelangsungan hidup pada perlakuan P2 (250 gram) diduga merupakan berat ideal untuk reproduksi aseksual pada teripang $H$. atra. Hasil penelitian Karim dkk. (2013) menyatakan bahwa tingkat kelangsungan hidup menurun pada teripang Holothuria leucospolita ukuran besar (500-1000 gr) sedangkan tingkat kelangsungan hidup tertinggi didapat pada perlakuan (250-500 gr) dengan persentase tingkat kelangsungan hidup sebesar 50\%. Hasil tingkat kelangsungan hidup Holothuriaedulis berukuran besar (300800 gr) memberikan tingkat kelangsungan hidup tertinggi sebesar 59,09\% dibandingkan ukuran kecil (140-250 gram) 13,6\%. Perbedaan berat tubuh dan jenis teripang dapat mempengaruhi tingkat kelangsungan hidupserta daya regenerasi teripang. Hartati dkk. (2016) menyatakan perbedaan berat tubuh teripang dapat mempengaruhi tingkat kelangsungan hidup dan daya regenerasi teripang. Purwati (2002) menyatakan ukuran spesimen yang digunakan dalam propagasi aseksual dapat menjadi penentu keberhasilan.

\section{Kualitas Air}

Berdasarkan pengukuran kualitas air selama penelitian hasil reproduksi aseksual teripang, kualitas air masih dapat dikatakan normal. Hasil pengukuran suhu berkisar 28$29^{\circ} \mathrm{C}$. Kordi (2009) menyatakan kehidupan dan pertumbuhan biota akuatik sangat dipengaruhi oleh suhu, apabila suhu tidak stabil akan menggagngu konsumsi oksigen biota akuatik. Kisaran suhu optimal bagi kehidupan ikan di perairan tropis berkisar 28$32^{\circ} \mathrm{C}$. Elfidasari (2012) menyatakan teripang mampu bertahan pada temperatur $25-35^{\circ} \mathrm{C}$. Lebih dari $35^{\circ} \mathrm{C}$ tubuh teripang akan mengalami inaktif akan tetapi tentakelnya masih dapat bergerak. Hyman (1995) dalam Kaenda dkk. (2016) menerangkan bahwa larva teripang mempunyai kisaran suhu optimum antara $2829{ }^{\circ} \mathrm{C}$ dan teripang dewasa dapat mentolerir suhu air dari $2831^{\circ} \mathrm{C}$.

Kisaran salinitas berdasarkan pengkuran selama penelitian 31-33 ppt. Kordi (2009) menyatakan salinitas air berpengaruh terhadap tekanan osmotik air, semakin tingi salinitas akan semakin besar pula tekakan osmotiknya Purwaningsi dan Ambriyanto (2003) dalam Tahe (2012) menjelaskan teripang menyukai perairan yang jernih, bebas dari polusi, air relatif tenang dengan mutu air yang cukup bagus dengan salinitas 29-33 ppt.

Derajat keasaman air sangat mempengaruhi tingkat kesuburan suatu perairan serta kehidupan jasad renik yang berada didalamnya, $\mathrm{pH}$ yang asam ataupun basa dapat membunuh biota akuatik. Kisaran $\mathrm{pH}$ yang didapatkan selama penelitian adalah 7,75- 8,17. Menurut Nybakken (1992) dalam Kaenda dkk. (2016) bahwa secara umum perairan laut maupun pesisir memiliki $\mathrm{pH}$ relatif stabil dan berada kisaran yang sempit, biasanya berkisar antara 7,7 8,4. Hasil penelitian ini diperkuat pula oleh Keputusan Menteri Lingkungan Hidup Nomor 51 Tahun 2004, bahwa untuk biota laut batas toleransi $\mathrm{pH}$ berkisar antara 78,5 .

Oksigen merupakan merupakan faktor pembatas bagi biota akuatik diamana oksigen dibutuhkan sebagai bahan untuk bernafas, jika kadar oksigen dalam suatu perairan tidak tercukupi maka dapat dipastikan semua aktifitas biota akuatik akan terhambat kisaran oksigen terlarut yang didapatkan selama penelitian 5-6 mg/l. Menurut Darsono (1999) kebutuhan oksigen optimum untuk teripang adalah DO 4-6 ppm. Kordi (2009) menyatakan rendahnya kadar oksigen dapat berpengaruh terhadapap fungsi biologis dan lambatnya pertumbuhan bahkan dapat mengakibatkan kematian.

\section{Kesimpulan}

1. Perbedaan berat tubuh memberikan pengaruhterhadap daya regenerasi teripang dimana proses pemulihan pada perlakuan P2 (250 gram) terjadi lebih cepat daripada perlakuan P1 (150 gram) dan P3 (350 gram). 
2. Berat ideal teripang ( $H$. atra) untuk reproduksi vegetatif yaitu 250 gram (P2) .

3. Persentase tingkat kelangsungan hidup tertinggi didapat pada berat 250 gramsebebsar 72,22\% namun tidak memberikan pengaruh terhadap pertumbuhan benih teripang hasil fission .

\section{Daftar Pustaka}

Anderson, D. P. (1996). Environmental factors in fish health: Immunological aspects, p. 289-305. In: Iwama G. and T. Nakanishi (eds.). The fish immune system. Academic Press, NewYork.

Barton, B,A., C, B, Schreck, dan L, D, Barton. (1987). Effects of chronic cortisol administration and daily acute stress on growth, physiological conditions, and stress responses in juvenile rainbow trout. DisAquat Org;2:173-85.

Conand, C., C. Morel and R. Mussard. (1997). A new study of sexual reproduction in holothurians: fission in Holothuria leucospilota populations on Reunion Island in the Indian Ocean. SPC Bechede-mer lnfo. Bull, 9: 5-11.

Darsono, P.(1999). Perkembangan Pembenihan Teripang Pasir, Holothuria Scabra Jaeger, di Indonesia. Jurnal Oseana. VOL. XXIV, NO. 3.

Dwiono, S, A, P. (2008). Teripang Indoesia: Strategi Mencapai Populasi Reproduktif Alami. Pusat Penelitian Oceanografi LIPI. Lombok.

Elfidasari, D., N, Noriko., W, Ninditasya dan T, A, Perdana.(2012). Identifikasi Jenis Teripang Genus Holothuria Asal Perairan Sekitar Kepulauan Seribu Berdasarkan Perbedaan Morfologi. Jurnal Al-Azhar Indonesia Seri Sains dan Teknologi. VOL. 1, NO. 3.

Emson, R. H \&P.V, Maldenov (1980). Fission and autotomy echinoderm. Oceanografi. Mar. Biol. Am, Rev. 18, 155-250.

Emson, R. H. \&I. C, Wilkie (1980). Fission and autotomy in echinoderms. Oceanogr. Mar. Biol. Amm. Rev.,18:155-250.

Satria, F, A. (2018). Pengaruh pemberian antibiotik alami (Jathropah Mulfida lin) terhadap pertumbuhan dan kelangsngan hidup benih teripang (Holothuria atra) hasil fission. Program studi budidaya

Perairan. Universitas Mataram.

Hartati, R., Widianingsih dan H, Endrawati (2016). The Growth of Sea cucumber Stichopus herrmanni After Transverse Induced Fission in Two and Three Fission Plane. Jurnal Ilmu Kelautan. Vol 21 (2).

Kaenda H., I, Ermayanti dan L, O, A, Afu. (2016). Hubungan Panjang Berat Teripang di Perairan Tanjung Tiram, Konawe Selatan. Jurnal Manajemen Sumber Daya Perairan. 2(2): 171-177.

Karim, A, R., R, Hartati dan Widianingsih (2013). Kemampuan Fission Teripang Holothuria Edulis dan Holothuria Leucospilota (Holothuridae) Ukuran yang Berbeda di Kepulauan Karimunjawa. Journal of Marine Research. Vol. 2, No. 1.

Karnila, R. (2011). Pemanfaatan Komponen Bioaktif Teripang Dalam Bidang Kesehatan. Faperika. Universitas Riau.

Kordi. (2009). Budidaya Perairan Buku Kedua. Bandung: Citra Aditya Bakti.

Muttaqin, R, A., R, Hartati dan E, W, Kushartanto (2013). Stimulasi Fission pada teripang Holothuria atra. Jurnal of Marine Research.Vol 2 (1).

Prastiwi, I, D. (2011). Pertumbuhan Karang Lunak Lobophytum Strictumhasil Transplantasi Pada Sistem Resirkulasi Dengan Kondisi Cahaya Berbeda. Fakultas Perikanan dan Kelautan. Institut Pertanian Bogor.

Purwati, P. (2002). Pemulihan Populasi Teripang Melalui Fission, Mungkinkah? Oseana. XXVII(1): :19-25.

Purwati, P dan S, A, P, Dwiono.(2004). Petunjuk Praktis Memperbanyak Teripang Melalui Pembelahan. Jakarta: Pusat Penelitian Oceanografi -LIPI.

Purwati, P. (2005). Teripang Indonesia: Komposisi Jenis dan Sejarah Perikanan. Oseana 30 (1), 12pp.

Purwati, S dan S, A, P, Dwiono. (2005). Fission Inducement in Indonesian Holothurians.SPC Beche-de-mer Information Bulletin.

Purwati, S dan S, A, P, Dwiono. (2007). Experiment On Fission Stimulation OfHolothuria Arta(Holothuroidea, Echinodermata): Changing In 
BodyWeight And Morphology. Mar Res Indonesia. 32 (1): 1-6.

Purwati, P dan S, A, P, Dwiono.(2008). Reproduksi Aseksual Sebagai Alternatif Pemulihan populasi Teripang. Ilmu Kelautan. 13(1): 37-42.

Purwati, P., S, A, p, Dwiono., L, F, Indriana., V, Fahmi. 2009. Shifting the natural fission plane of Holothuria atra (Aspidochirotida, Holothuroidea, Echinodermata). SPC Beche-de-mer Information Bulletin. 23 (1): 1-4.

Rottman , R, W., R, Floyd dan R, Durborow. (1992). The Role of Stress in Fish Disease. SRAC Publication No. 474.

Rumiyati, B. 2014. Pengaruh Kedalaman air terhadap tingkah laku dan lama Hidup Teripang Lokal (Phylloparus sp.) Selama Masa Adaptasi Di Bak Pemeliharaan. Fakultas Perikanan dan Kelautan. Universitas Airlangga.
Satria, F, A. 2018. Pengaruh Pemberian Antibiotik Alami (Jathropa Mulfida Lin) Terhadap Pertumbuhan Dan Kelangsungan Hidup Benih Teripang (Holothuria Atra) Hasil Fission. Program Studi Budidaya Perairan. Universitas Mataram.

Smilek, K. R. and D. I. Hembree. 2012. Neoichnology of Thyonella gemmata: A Case Study for Understanding Holothurian Ichnofossils. The Open Paleontology Journal. 4 : 1-10.

Tahe, S. 2013. Present Status Produksi dan Budidaya Teripang di Sulawesi Selatan. Prosiding Forum Inovasi Teknologi Akuakultur. Balai Penelitian dan Pengembangan Budidaya Air Payau.

Widianingsih, T., R, Hartatidan Endrawati.(2013) Penerapan Teknologi Fission Pada Budidaya Teripang.Majalah Info. Edisi XVI. No. 2. 